\title{
BRAZILIAN PUBLIC HEALTH AND COVID-19: WHAT THE BRAZILIAN POPULATION EXPECTS 1
}

\author{
Salud pública brasileña y COVID-19: lo que espera la población brasileña
}

Saúde pública brasileira e COVID-19: o que a população brasileira espera

Received: april/2020

Accepted: april/2020

Available online: june/2020

\begin{abstract}
Yuri Miguel Macedo, Mestrando em Ensino e Relações Étnico Raciais, Universidade Federal do Sul da Bahia - Universidade Federal do Espirito Santo, Brasil. E-mail: yurimacedo@id.uff.br

Joaquim Lemos Ornellas, Licenciado em Biologia - Ciências ambientais/ecologia da conservação, Universidade Federal do Sul da Bahia, Brasil. E-mail: joaquimor_2@hotmail.com
\end{abstract}

Helder Freitas do Bomfim. Mestre em Ciências Sociais. Universidade do Estado da Bahia, Brasil. E-mail: hfreitas@uneb.br

\begin{abstract}
This text aims in a systemic and classic way to conceptualize the coronavirus (COVID-19), following the proposal analyzes the cases of infection in the countries Brazil and Italy, in order to obtain results that may be significant to the quarantine processes acquired by both countries, through a literary review. The data collection base is the European Center for Disease Prevention and Control. After analyzing the data collected at the base, it was thought about how public policies exterminate subordinated subjects, where the black-poor-peripheral population of Brazil will be put in check to corroborate the social and effective consequences of the restriction of the rights of Brazilian citizens.
\end{abstract}

Keywords: COVID-19, Brazil, Subalternated.

Resumen: Este texto tiene como objetivo una forma sistémica y clásica de conceptualizar el coronavirus (COVID-19), luego de que la propuesta analiza los casos de infección en los países de Brasil e Italia, a fin de obtener resultados que puedan ser significativos para los procesos de cuarentena adquiridos por ambos países. , a través de una revisión literaria. La base de recopilación de datos es el Centro Europeo para la Prevención y el Control de Enfermedades. Después de analizar los datos recopilados en la base, se pensó en cómo las políticas públicas exterminan a los sujetos subordinados, donde la población negra-pobre-periférica de Brasil será controlada para corroborar las consecuencias sociales y efectivas de la restricción de los derechos de los ciudadanos brasileños.

Palabras clave: COVID-19, Brasil, Subalterno.

1 Texto original em português “COVID - 19 NO BRASIL: o que se espera para população subalternizada?” publicado em Português na Revista Encantar v. 2, p. 1-10, 2020 
Resumen: O presente texto visa de forma sistêmica e clássica conceituar o coronavírus (COVID-19), seguindo a proposta analisa os casos de infecção nos países Brasil e Itália, a fim de obter resultados que possam ser significantes aos processos de quarentena adquirido pelos ambos países, por meio de uma revisão literária. A base de coleta de dados é a European Centre for Disease Prevention and Control. Após a análise dos dados coletados na base, foi pensado em como as políticas públicas exterminam os sujeitos subalternizados, onde será colocado em xeque a população preta-pobre-periférica do Brasil para corroborar as consequências sociais e efetivas, do cerceamento de direitos dos cidadãos brasileiros.

Palavras-chave: COVID-19, Brasil, Subalternizados.

\section{CORONAVIRUS (COVID-19)}

Coronavirus is a family of viruses that cause respiratory infections, in the case of the pandemic of this new agent, it was discovered on December 31, 2019 in Wuhan in China. The current virus causes their carriers to have the disease called coronavirus (COVID-19). The first human coronaviruses were highlighted for the first time in 1937, however, it was in 1965 that the virus was described as coronavirus, due to the microscopic profile, resembling a crown.

Most people are infected with common coronaviruses throughout their lives, with young children being more likely to become infected with the most common type of virus. The most common coronaviruses that infect humans are alpha coronavirus 229E and NL63 and beta coronavirus OC43, HKU1.

With the emergence of the coronavirus pandemic all over the world beginning the year 2020, it is necessary to rethink since when this virus is present in society. And for that, it will be contributed since when COVID appears in scientific studies in the world. Some studies were found on the coronavirus, the ones that stood out were: "Episodic Evolution Mediates Interspecies Transfer of a Murine Coronavirus", written by Baric RS, Yount B, Hensley L, Peel SA, Chen W. in 1997; “An Outbreak of Coronavirus OC43 Respiratory Infection in Normandy, France” written in 2003 by Astrid Vabret, Thomas Mourez, Stéphanie Gouarin, Joëlle Petitjean and François Freymuth, who studied the OC43 HCoV infection outbreak in Normandy, France, in February and March 2001.

According to Vabret et al. (2003), the virus of the Coronaviridae family, are single-strand, positive sense RNA viruses and are not a cause of serious disease in humans. Two different human coronaviruses were known: 229E and OC49, both of which cause a common cold, which may 
eventually cause low respiratory disease. Epidemics caused by coronavirus are unknown, but outbreaks of low respiratory disease, similar, to some extent, to the current pandemic, are not entirely unknown.

Different coronaviruses cause various diseases in animals since feline infectious peritonitis, the first of the diseases caused by coronavirus to be described as early as 1912. It was only in 1937 that the first coronavirus was isolated, from chickens, and it was only in the mid-1960s that his role in human disease has been recognized (Hsiang's, 1991).

Despite not having its RNA segmented like influenza viruses, coronaviruses are subject to frequent mutations, which is why the emergence of a new coronavirus is not a cause for surprise. In fact, coronaviruses have long been used as a model for investigating mutations that allow species to leap (Baric et al., 1997, 1999).

Emerging infectious diseases are not the result of paranoia, they have occurred and have been occurring for thousands of years, for example we have bubonic plague, Eltor cholera, Spanish flu, AIDS.

It is necessary to remember that in 1894 , the third pandemic of bubonic plague began in Hong Kong, it took five years for it to arrive in Brazil. This time, it took a few days for the first suspicious cases to arrive.

This should be considered as the contemporary pandemic, as it plagues and causes countless nations to be stopped and strong in the fight against the virus. COVID-19 came to expose that there is a globalization of the virus and that there is still time for nations like Brazil to rethink public health policies so as not to exterminate its minority. It is, therefore, a premeditated need, not a government fantasy or fetish.

\section{CORONAVIRUS IN ITALY}

On January 31, 2020, the World Health Organization (WHO) declares raising the situation of COVID-19 to an international emergency, the following day Italy discloses its first three cases of 
corona virus in the country, suspends flights from China and declares national emergency. After 22 days since the release of the first positives in the country, Italy reaches 17 confirmed cases in the country.

The concern with the virus is in its power of exponential growth, this form of growth works in this way: on day one there is an infected person, the next day there are two people. On the third day, four will be infected. On the fourth day eight infected and so selectively. On the fifteenth day there will be 16,384 infected.

In this regard, it is necessary to analyze the age structure of Italy and the risk groups associated with COVID-19. According to Chen (et al., 2020) the group most vulnerable to the virus is men over 50 years old and with the presence of comorbidities. In these cases, viral infection can progress to fatal respiratory diseases or acute respiratory failure.

Italy has $62,402,659$ inhabitants, of which $38 \%$ of the population is 55 years old or more, $10,193,295$ people of the Italian population fit the age profile of the new virus, this information is also useful for thinking about how the spread of the virus should proceed. virus (CIA, 2020). According to data collected by the European Center for Disease Prevention and Control (2020), 31 days after the initial case of COVID-19 in the country, Italy presents 1,128 cases, on 03/03 the official cases increase to 1,835 .

On the fortieth day since the first case appeared in the country, Italy decrees a national quarantine, surpassing 7 thousand confirmed cases. Two days after the national quarantine, all bars and restaurants are closed (12,462 cases). You can see in the graph below that even after the mandatory quarantine is imposed, the number of daily cases continues to increase. On its 53rd day, the number of confirmed cases in Italy reached approximately 59 thousand cases and 5,476 deaths, due to the spread of the virus, the Italian government decides to close all non-essential services in the country. 

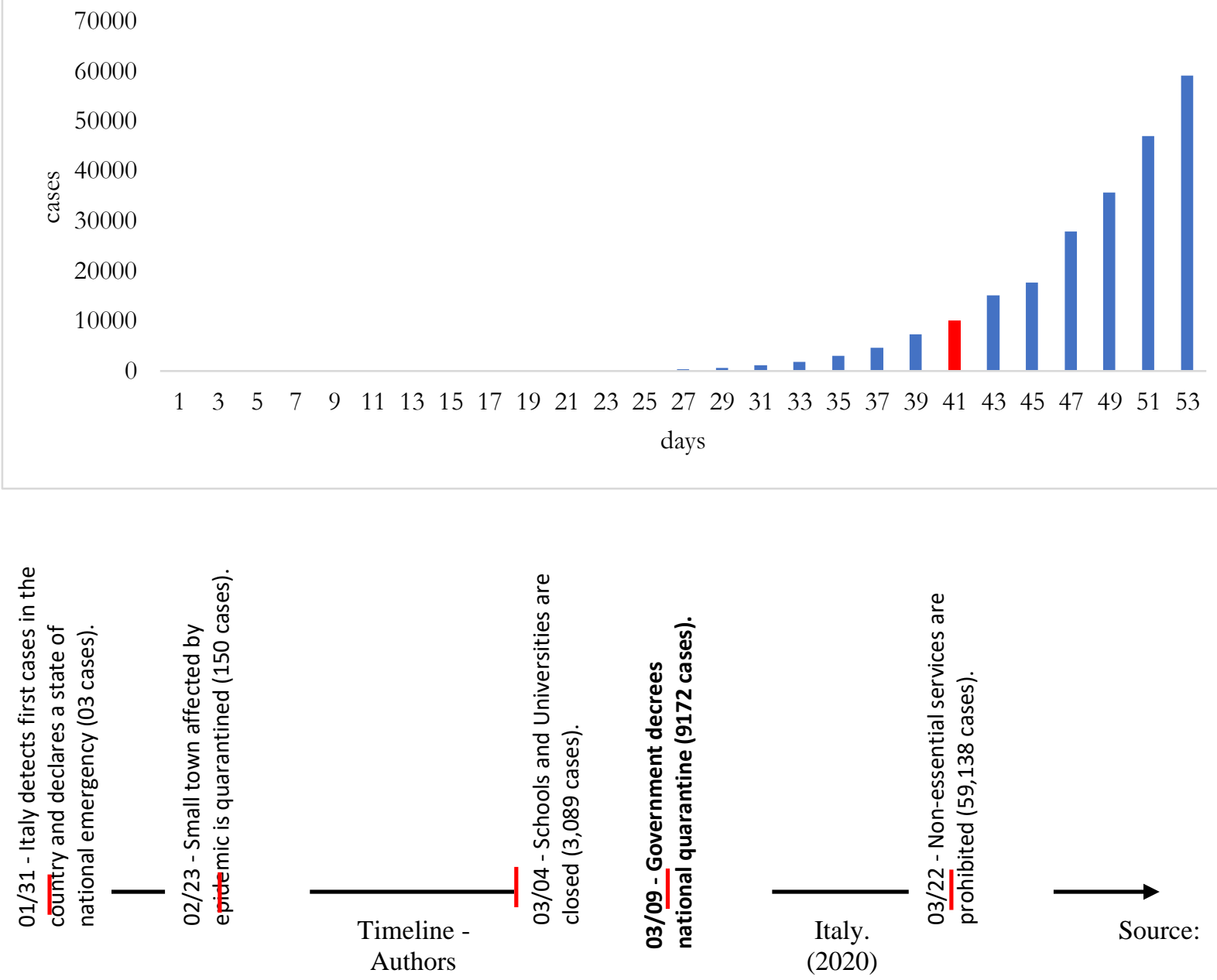

Timeline - Itály.

Source: Authors (2020)

\section{CORONAVIRUS IN BRAZIL}

The first positive test for COVID-19 in the country appears on February 26, 2020 imported by a naturalized citizen of São Paulo who had recently visited Italy. Five days after the first case, another positive case is confirmed in the country and in just 11 days the sum of confirmed cases reaches 25 people.

The Brazilian population is estimated at 211 million inhabitants (IBGE, 2020), of these 8\% are men who fit the age profile of the disease, however new cases of the disease are advancing rapidly 
in the country. While Italy decrees a national quarantine 10 days after the first positive cases, the quarantine is regulated by the Ministry of Health 16 days after the detection of the first case, totaling more than 100 confirmed cases.

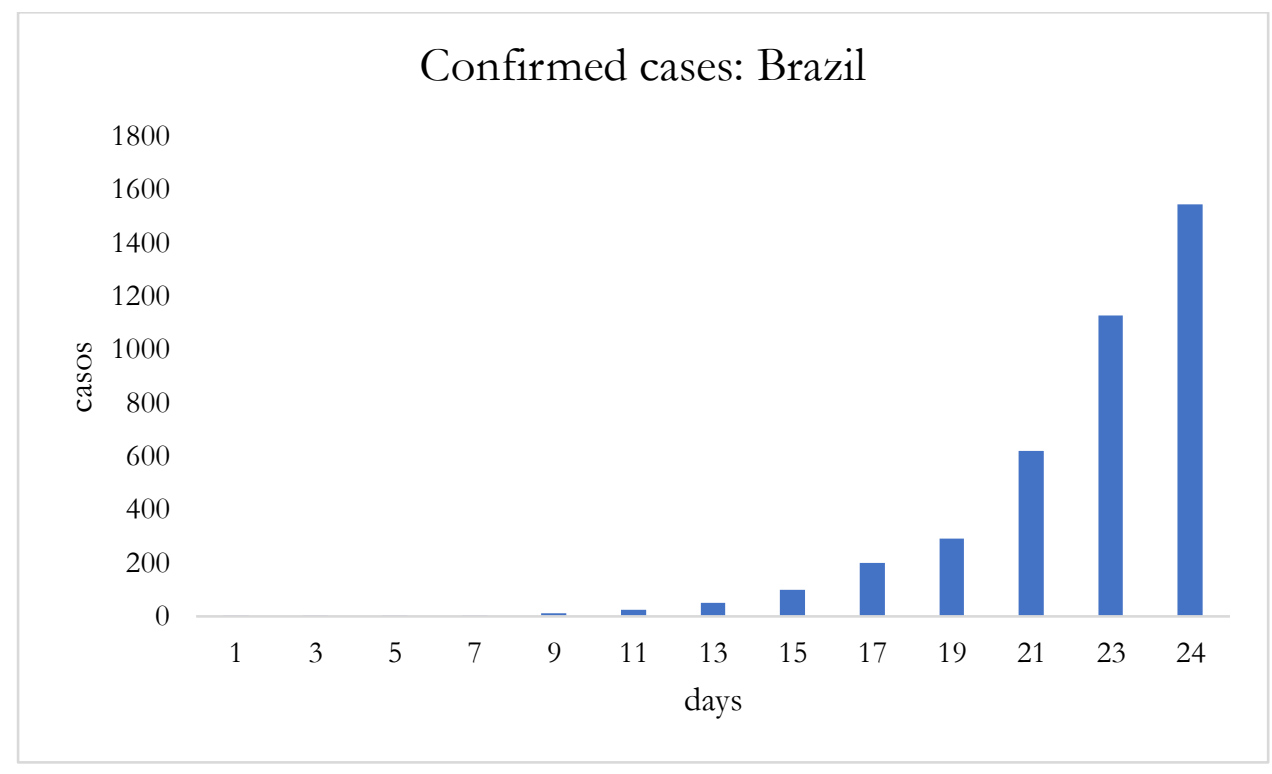

Confirmed Cases - Brazil.

Source: Authors (2020)

According to the Observatório COVID-19 BR (2020) the current rate of duplication of infected persons given the containment measures (23/03) varies between 2.4 and 2.8 days. Following approximately the pattern of propagation in Italy and not decreasing even with the measures of containment, Brazil already exceeds the quantity of Italy in comparison on its 23rd day with 1128 confirmed cases against 17 of the Italians. According to estimates by the authors, if the virus continues to follow this rate of infection, it is expected that by March 28, there will be between 6,591 and 8,473 cases across the country. 


\section{POLICIES FOR THE EXTERMINATION OF THE BLACK-POOR-PERIPHERAL POPULATION IN BRAZIL}

The lower strata of society, constituted by the specific ways of excluding markets from political and legal representation, and the possibility of becoming full members in the dominant social strata, these are the subordinates. (Spivak, 2010, pages 13-14)

The infection reduction processes in all parts of the world, occur through the isolation and quarantine of society, hygiene and measures to detail the contamination. In Brazil, the following measures were adopted by the Ministry of Health -MS (2020): Surveillance, Laboratory support, Infection control measures, Assistance, Pharmaceutical assistance, Health surveillance - Health measures at entry points, Risk communication and Management. And both are based initially on hand hygiene with water and soap and / or $70 \%$ gel alcohol.

Regarding the prevention process, there are guidelines that the MS (2020) indicated is: -Wash your hands with soap and water or use alcohol gel; -Cover your nose and mouth when sneezing or coughing; - Avoid agglomerations if you are ill; -Keep environments well ventilated; - Do not share personal items. And following these guidelines, the chance of being infected with COVID-19, the chance is decreased.

In view of the guidelines presented, we can observe the following aspects, so that the population can wash their hands and perhaps have soap, or $70 \%$ gel alcohol, basic sanitation and 
water supply policies are necessary. Which in the past corresponds, according to the National Sanitation Information System - SNIS, in 2018, that the average of the population that has sewage is $53.2 \%$ - an average of 107.5 million people, of its totalities, the southeast regions with $79.2 \%$ have sewage, followed by the Midwest region with $52.9 \%$, then the south region with $45.2 \%$, the penultimate northeast with $28 \%$ and finally the north of Brazil with $10.5 \%$ (Brasil, 2018).

Regarding water supply in Brazil, and according to SNIS (2018), the population that has access to water is on average 169.1 million people, that is, $83.6 \%$, distributed with $91 \%$ in the southeast region, $90.2 \%$ in the south region, $89 \%$ in the Midwest region, $74.2 \%$ in the northeast region and $57.1 \%$ in the north region of the country.

In addition to measures that basically require sewage and water supply, it is necessary to rethink these public services in maintaining access for all and especially in the prevention of COVID19. It is necessary to analyze the processes involving capital and its actors, that is, to see how the working class that is the majority in the country, can be curtailed the right to purchase, with wage loss, unemployment and the non-receipt of wages that is proposed by the Federal Government?

What is to be said about the guidelines for avoiding agglomerations, what is questionable and which is being analyzed are the peripheries and slums throughout Brazil which, according to Ivo (2010),

[...] the peripheries are hybrid and heterogeneous places in a daily life shared by subjects who live in adversity and in the search for social justice and for social rights and rights over the city, such as access to housing, health, transport, education and cultural consumption, which interact and blend with the standardized, rational, "legitimated" city, overcoming old moral notions of culpability of poverty or risky territories, which may suggest stigmatized meanings of the criminalization of poverty.

Public Policies mentioned above, brings with them positive consequences for the social welfare and health of the population that has the Unified Health System as its only way to improve life. And for that, Leoneti et.a. (2011), corroborates that public policies aimed at improving basic sanitation conditions in communities are effective in reducing mortality and [...] diseases related to the conditions of the environment in which they live. The peripheries, or slums, according to Jodelet (1998, p.48), are referred to those who, marked with the seal of difference, whether physical (color, 
race, disability, etc.) or linked to a group belonging ( national, ethnic, community, religious, etc.), are distinguished within a social or cultural group and can be considered there as a source of malaise or threat.

\begin{abstract}
The population in the favelas has grown dramatically in recent decades, mainly since the end of the 1950s. Currently, we have a decrease in poverty rates, camouflaged by the evaluation criteria. Although today's favela has a TV, refrigerator, stove, VCR and even a microwave, this improvement in quality of life comes up against the inertia of experiencing exclusion for generations. The lack of prospects for the future and jobs for the younger generations portrays a subsequent reproduction of poverty and social exclusion (VERAS, 1999).
\end{abstract}

Veras, in his statement, brings to light the reality that is lived in the favelas and peripheries, but far beyond policies and government projects, equitable principles of income distribution, work, leisure, education, health and basic sanitation. That is everyone's right, and the State's obligation.

\title{
FINAL CONSIDERATIONS
}

In view of the data presented on those infected and dead in Brazil and Italy, it is possible to think about what destinations are being mapped out by the State for the minority, the majority being in Brazil black-poor-peripheral.

Taking a proportion of 4 countries: China (Asia), Italy (Europe), Pakistan (Asia) and Nigeria (Africa), on March 23, 2020, both not chosen by chance, China as the first country to show symptoms of COVID-19, has a population of 1,394,550,000 people and the number of infected people reaches $0.005854 \%$ of the total population. Moving on to Italy, which was chosen for having the infected curve similar to that of Brazil, which has a population of $68,480,000$ people and the number of cases is on average $0.0863 \%$ of the population. In the case of Pakistan and Nigeria, they were chosen for presenting the population close to the number of inhabitants of Brazil. For this, Pakistan, has $216,000,000$ inhabitants and its average confirmed cases in the country was $0.0000036296 \%$ of the population, in parallel to this Nigeria with 193,392,517 inhabitants presented the average of confirmed cases of COVID-19 in $0.0000015512 \%$ of the population. 
For the month of April 2020, where the peak in the number of cases is expected, Brazil can expect the following situations: Situation $1=209.300 .000 * 0.005854 \%=\mathbf{1 . 2 2 5 . 2 4 2}$ on average infected; Situation $2=209,300,000 * 0.0863 \%=\mathbf{1 8 , 0 6 2 , 5 9 0}$ on average infected; Situation $3=$ $209.300 .000 * 0.0000036296 \%=\mathbf{7 5 9}$ on average of infected and Situation $4=209.300 .000 *$ $0.0000015512 \%=\mathbf{3 2 4}$ on average of infected. In situations 3 and 4 , this possibility has already been ruled out, since, on March 24, 2020, they already had 25 dead and 1,546 confirmed cases, on the twenty-fourth day of the quarantine.

More than declaring a minimum state is necessary, it is necessary to rethink the actions of Sanitary Sewers in these subordinated areas; Water supply as a minimum condition for all citizens; Access to free, public and quality education; public health promotion policies. Well, it is in public institutions and universities that more than $90 \%$ of science is produced in Brazil.

Finally, it is already known which paths the state policy takes in Brazil, which by the way thinks of capital as the only way out, scrapping the rights and conquests of citizens, workers and workers who are in the slums, peripheries and ghettos. We have faith and requests to God, Kavungo, Obaluaie, Ajansu, Azoani and all the Gods of the earth, health for us, and for everyone.

\section{REFERENCES}

Baric RS, Sullivan E, Hensley L, Yount B, Chen W. Persistent infection promotes cross-species transmissibility of mouse hepatitis virus. J Virol 1999;73:638-49.

Baric RS, Yount B, Hensley L, Peel SA, Chen W. Episodic evolution mediates interspecies transfer of a murine coronavirus. J Virol 1997;71:1946-55.

CHEN, Nanshan et al. Epidemiological and clinical characteristics of 99 cases of 2019 novel coronavirus pneumonia in Wuhan, China: a descriptive study. The Lancet, v. 395, n. 10223, p. 507-513, 2020.

CIA. Central Intelligence Agency. Europe: Italy. Disponível em: https://www.cia.gov/library/publications/the-world-factbook/geos/print_it.html. Acesso em: 23 de março de 2020. 
ECDC. European Centre for Disease Prevention and Control. data on the geographic distribution of COVID-19 cases worldwide. Disponível em:

https://www.ecdc.europa.eu/en/publications-data/download-todays-data-geographic-distributioncovid-19-cases-worldwide. Acesso em: 23 de março de 2020.

$\begin{array}{llll}\text { Hsiang's } & \text { M. } & \text { Coronaviridae. } & \text { Available }\end{array}$ from: http://www.stanford.edu/group/virus/1999/mhsiang/corona.html [2003 abr 20].

IBGE. Instituto Brasileiro de geografia e Estatística. População, 2020.

IVO, Anete BL. Uma periferia em debate: questões teóricas e de pesquisa. Cafajeste. CRH, Salvador, v. 23, n. 58, p. 15 a 15 de abril de 2010. Disponível em $<$ http://www.scielo.br/scielo.php?script=sci_arttext\&pid=S0103$49792010000100001 \& \operatorname{lng}=$ en $\& n r m=$ iso> .

Jodelet, D. (1998). A alteridade como processo e produto psicossocial. Em A. Arruda (Org.), Representando a alteridade (pp. 47-67). Petrópolis, RJ: Vozes.

LEONETI, Alexandre Bevilacqua; PRADO, Eliana Leão do; OLIVEIRA, Sonia Valle Walter Borges de. Saneamento básico no Brasil: considerações sobre investimentos e sustentabilidade para o século XXI. Rev. Adm. Pública, Rio de Janeiro , v. 45, n. 2, p. 331-348, Apr. 2011 . Available from $<$ http://www.scielo.br/scielo.php?script=sci_arttext\&pid=S0034-

$76122011000200003 \& \operatorname{lng}=\mathrm{en} \& \mathrm{nrm}=\mathrm{iso}>$.

OBSERVATÓRIO COVID-19 BR. 23 de março de 2020, 22:49. Disponível em: https://covid19br.github.io/. Acesso em: 23 de março de 2020.

SPIVAK, Gayatri Chakravorty. Pode o subalterno falar? 1. ed. Trad. Sandra Regina Goulart Almeida; Marcos Pereira Feitosa; André Pereira. Belo Horizonte: Editora da UFMG, 2010.

Vabret A, Mourez T, Gouarin S, Petitjean J1, Freymuth F. An outbreak of coronavirus OC43 respiratory infection in Normandy, France. Clin Inf Dis 2003;36:985-9. https://doi.org/10.1086/374222

VÉRAS, M. Exclusão social - um problema brasileiro de 500 anos. In: SAWAIA, B. (Org). As artimanhas da exclusão. Petrópolis: Vozes, 1999. p. 27-52. 